\title{
Ascorbic acid status of Europeans resident in the tropics
}

\author{
By T. C. HINDSON* \\ British Military Hospital, Singapore \\ (Received 6 January 1970-Accepted 20 April 1970)
}

\begin{abstract}
I. A survey was made of ascorbic acid concentrations in white blood cells of apparently healthy European men and women living in the tropical climate of Singapore.

2. The survey showed that there was a significant fall in these concentrations in men who had been resident for more than 4 months. Levels in women did not show a significant decrease.
\end{abstract}

It has been shown that vitamin $\mathrm{C}$ is beneficial in the treatment of prickly heat, a disease of sweat glands in the tropics (Hindson, 1968). This survey of ascorbic acid levels in white blood cells was therefore carried out in apparently healthy European men and women living in the tropical climate of Singapore.

\section{MATERIALS AND METHODS}

Blood samples were taken from apparently healthy volunteers drawn from blood donors, hospital staff and married couples from neighbouring military units who had been resident in the tropics for periods of up to 30 months, the normal length of tour of duty for British forces and their families in Singapore. Those who admitted to taking any vitamin supplements in the previous 3 months were excluded. The age range was from is to 47 years.

Ascorbic acid levels in white blood cells (wbc) were estimated by the method of Denson \& Bowers (196r).

\section{RESULTS}

The results (Table I) show that there was a significant fall in the levels of ascorbic acid in the wbc of men after 4 months residence in the tropics when not taking vitamin supplements. The mean fall was $6.66 \mu \mathrm{g} / \mathrm{Io}^{8} \mathrm{wbc}$, bringing the average level to $22.54 \mu \mathrm{g} / 10^{8} \mathrm{wbc}$, below the normally accepted lower limit of $25 \mu \mathrm{g} / 10^{8} \mathrm{wbc}$ in western Europe.

The mean decrease in women's levels of $2 \cdot 46 \mu \mathrm{g} / 10^{8}$ wbc was not statistically significant.

\section{DISCUSSION}

There is no obvious cause for the significant drop in white blood cell vitamin $\mathrm{C}$ levels in men after 4 months residence in the tropics. Allen, Andrews \& Brook (1967) showed that women tend to have higher levels of the vitamin in their wbc.

* Present address: British Military Hospital, 44 Münster/Westf., von Esmarch Strasse 56, West Germany. 
It is unlikely that dietary intake of vitamin $\mathrm{C}$ varied between men and women in Singapore and indeed it is probable that it would be higher in both groups than in residents in western Europe. This is due to the need to drink large quantities of fluid in the tropics. This was frequently fresh lime juice which was readily available and popular with the military community.

Table I. Mean values with their standard errors for ascorbic acid levels in the white blood cells of Europeans resident in the tropics

\begin{tabular}{|c|c|c|c|c|}
\hline \multirow[t]{2}{*}{$\begin{array}{l}\text { Time in tropics } \\
\text { (months) }\end{array}$} & $\begin{array}{l}\text { No. of } \\
\text { subjects }\end{array}$ & $\begin{array}{l}\text { Ascorbic acid } \\
\left(\mu \mathrm{g} / \mathrm{IO}^{8} \mathrm{wbc}\right)\end{array}$ & $t$ & $P$ \\
\hline & \multicolumn{4}{|c|}{ Males } \\
\hline $0-4$ & 34 & $29 \cdot 20 \pm I \cdot 26$ & - & - \\
\hline $4-30$ & 96 & $22.54 \pm 0.70$ & - & - \\
\hline \multirow{2}{*}{ Mean decrease } & - & $6 \cdot 66$ & $4 \cdot 63$ & $<0.001$ \\
\hline & \multicolumn{4}{|c|}{ Females } \\
\hline $0-4$ & 26 & $32 \cdot 34 \pm 1 \cdot 62$ & - & - \\
\hline $4-30$ & 56 & $29 \cdot 88 \pm I \cdot 20$ & - & 一 \\
\hline Mean decrease & 一 & $2 \cdot 46$ & $1 \cdot 212$ & $<0.3$ \\
\hline
\end{tabular}

Men produce more sweat for a given thermal stimulus than women on a weight for weight basis, and in the climate of Singapore sweating was profuse; however, only insignificant quantities of vitamin $\mathrm{C}$ have been detected in sweat collected from acclimatized subjects by various investigators (Lugg \& Ellis, I954; Sargent, Robinson \& Johnson, I944), an observation confirmed by the author on ten subjects previously saturated with vitamin $\mathrm{C}$.

It has, however, been shown that, although only insignificant quantities of vitamin $\mathrm{C}$ are lost in sweat itself, the vitamin is utilized in increased quantities in the process of sweating (Wright \& MacLenathen, 1939). It may be, therefore, that the vitamin is necessary in larger quantities in the tropics to ensure the normal function of hyperactive sweat glands. Whatever may be the cause of the low cellular levels, the results suggest that European men residing in the tropics might benefit from vitamin $\mathrm{C}$ supplements to their diet.

I am indebted to Dr N. T. Pollitt and to Roche Products Ltd, Welwyn Garden City, England, for financial and technical assistance and to my technicians Mrs S. Birch and Mrs D. Williamson for their enthusiastic co-operation.

\section{REFERENCES}

Allen, M. A., Andrews, J. \& Brook, M. (1967). F. Diet, Food, Catering, Child Nutrition 21, no. 3, p. г 36. Denson, K. W. \& Bowers, E. F. (1961). Clin. Sci. 21, 157.

Hindson, T. C. (1968). Lancet i, 1347.

Lugg, J. W. H. \& Ellis, F. P. (1954). Br. F. Nutr. 8, 71.

Sargent, F., Robinson, P. \& Johnson, R. E. (I944). J. biol. Chem. r53, 285.

Wright. I. S. \& MacLenathen, E. (1939). F. Lab. clin. Med. 24, 804. 